\title{
RESPONSE OF HARDWOOD STEM CUTTINGS OF GUAVA (Psidium guajava L.) TO VARIOUS GROWTH AND ROOT PROMOTING REGULATORS. \\ Samaan, L. G. ${ }^{1}$; E. F. A. EL-Dengawy² and Maiada E. EL-Zayat ${ }^{1}$ \\ ${ }_{1}^{1}$ Department of Pomology, Fac. of Agric., Mansoura Univ., Egypt. \\ 2 Dept. of Pomology, Fac. of Agric., Damietta branch, Mans.Univ., Egypt.
}

\begin{abstract}
The present investigation was conducted to study the effect of 3 solutions of growth and root-induced regulators, Indolebutyric acid (IBA) at 4000ppm, Hydrogen Peroxide $\left(\mathrm{H}_{2} \mathrm{O}_{2}\right)$ at $3.5 \%$ and Vitamin $\mathrm{B}_{12}$ at $24 \mathrm{mg} / \mathrm{L}$ along with wounding process, either solely or in interactions, on rooting ability of hardwood cuttings of guava cv. Balady (Psidium guajava L.). The basal portion of wounded and non-wounded cuttings just before inserted in the planting medium (Sand and Peatmoss 1:1 v/v) were dipped in these solutions for 30 second each.

Growth and root-induced regulators were significantly affected buds burst and survival percentages per cutting. A similar effect was shown on number of shoots and leaves per cutting at 1.5-month-old, along with rooting percentage, primary roots number, primary root length and secondary roots number per cutting at 3 month-old. Maximum average of buds burst \% at 8 -week-old (81.52\%) and buds survival \% at 12 -week-old (62.83\%) along with more number of shoots/cutting (3.43 shoots), more number of leaves/cutting (5.75 leaves), maximum rooting percentage (70.67\%), more primary roots number/cutting (24.96 roots) and maximum primary root length/cutting $(8.38 \mathrm{~cm})$ were noticed in hardwood wounded cuttings pre-planting treated with dipping in $\mathrm{H}_{2} \mathrm{O}_{2}$ solution at $3.5 \%$ and in IBA solution at $4000 \mathrm{ppm}$ for 30 second each $\left(T_{12}\right)$. More secondary roots number/cutting (11.34 roots) was tabulated in wounded cuttings treated with wounding process only $\left(\mathrm{T}_{8}\right)$. The corresponding average results in non-wounded treated cuttings indicated that maximum buds burst percentage (72.65\%) was in cuttings treated with $\mathrm{H}_{2} \mathrm{O}_{2}$ solution $\left(\mathrm{T}_{3}\right)$. Maximum buds survival percentage $(53.05 \%)$, more shoots number per cutting (2.55 shoots), more leaves number/cutting (4.89 leaves), maximum rooting percentage $(43.00 \%)$ and more primary roots number/cutting (16.65 roots) were observed in cuttings treated with $\mathrm{H}_{2} \mathrm{O}_{2}$ at $3.5 \%$ and IBA at $4000 \mathrm{ppm}$ for 30 second each $\left(\mathrm{T}_{5}\right)$. Maximum primary root length/cutting $(7.10 \mathrm{~cm})$ and more secondary roots number/cutting (5.67 roots) were recorded for non-wounded cuttings treated with IBA at $4000 \mathrm{ppm}$ for 30 second $\left(T_{2}\right)$.
\end{abstract}

\section{INTRODUCTION}

Guava (Psidium guajava L.) belongs to the family Myrtaceae. Recent time, it is grown all over the world for its high nutritious values, good taste and wider adaptability. Moreover, guava trees are prolific in bearing and they bear two crops a year that are summer and winter. Such yields are of a high remunerating value even without much care. Furthermore, the trees are fairly salt and drought resistant. Therefore, they can grow on different soil types, sandy, clay, deep, shallow and acid to alkaline at $\mathrm{PH}$ values ranged from 4.5 to 8.2 (EL-Baradi, 1975). Guava fruit is the rich source of vitamin C (10 times more than tomatoes) and its juice has 2 to 5 times more vitamin $c$ than the 
fresh orange juice (Hartmann et al., 1981). Accordingly, guava trees are commonly considered as "the apple of the tropics" (Prakash et al., 2002).

In Egypt, guava is one of the common and important fruits, fresh fruits, juice and canned products are gaining much popularity. It is grown over an area of 38,873 feddan producing annually 314,438 ton (The Ministry of Agriculture statistics, 2006). The usual method to propagate guava trees is from seeds sowing immediately after extraction. Seedling to tree is generally long lived, have long juvenile phase and is not true to type which bears fruit of variable size and quality (Mitra and Bose, 1990).

Referring to the risk of guava propagation by sowing seeds, the uneconomical situation of propagation by air layering (laborious and time consuming) or grafting and budding (need suitable rootstocks beside taking long time and requiring more care with very little success) along with the great demand for true to type guava trees (Ahmad, 1961; Tahir et al., 1998 and Tahseen-Ullah et al., 2005). Propagation through cuttings has got the attention of many workers in the field of guava propagation. Although guava cuttings are hard to root, they have been practiced by different scientists through the application of various root promoting hormones. Numerous natural and synthetic auxins such as Indoleacetic acid (IAA), Indolebutyric acid (IBA), naphthaleneacetic acid (NAA), 2,4-dichloro-phenoxyacetic acid (2,4-D) and paclobutrazol (Mukhtar et al.,1998; Debnath and Maiti,1990). These root-induced hormone chemicals are utilized for several purposes in Horticulture and Agriculture such as formation of adventitious roots from stem cuttings, micro-propagation of plant species, fruit setting...etc. (Baloch,1994).

Rooting is a crucial step in the successful propagation of guava by cuttings. Early studies with guava cuttings and other fruits having cuttings difficult to root were cleared the positive effects of certain growth and root promoting regulators to overcome some of the inherent difficulties encountered by the cutting to root. The present investigation was a trial in this line; it was initiated to find out the rooting ability of guava hardwood stem cuttings by the application of three growth and root promoting regulators, $\mathrm{H}_{2} \mathrm{O}_{2}$, IBA and vitamin $\mathrm{B}_{12}$ used either solely or in combinations along with their interactions with wounding process. This study was to obtain further information on the activities of such root-induced hormone chemicals and describe the scope of clonal propagation of guava by hardwood stem cuttings.

\section{MATERIALS AND METHODS}

The experiment was conducted in a private nursery equiped with mist irrigation unit and located at Om EL-Reda, Damietta governorate, Egypt during 2008 and 2009 seasons.

Cutting propagation: Hardwood stem cuttings of guava cv. Balady were taken from fruiting guava trees at 15 -years-old grown in a private orchard located at the same district of nursery. Shoots source of cuttings, one yearold, are split wounded at the base portion of cuttings $(5 \mathrm{~cm})$ in the first week of March, two weeks before they were taken. The cuttings wounded and non- 
wounded were made of uniform size $25 \mathrm{~cm}$ long and nearly one $\mathrm{cm}$ thick, having at least 4 buds and 2 mature leaves.

Application of growth and root promoting regulators: Just before the cuttings were inserted in the planting medium their basal portions $(5 \mathrm{~cm})$ were dipped in indolebutyric acid (IBA) solution at 4000 ppm, Hydrogen Peroxide $\left(\mathrm{H}_{2} \mathrm{O}_{2}\right)$ solution at $3.5 \%$ and vitamin $\mathrm{B}_{12}$ solution at $24 \mathrm{mg} / \mathrm{L}$ for 30 second each. These regulators were used with wounded and non-wounded cuttings either solely or in combinations. The former regulator (IBA) was prepared according to the formula i.e., $1 \mathrm{mg}$ of IBA (in crystal form) in $1 \mathrm{~L}$ of distilled water to make 1ppm solution (Hartmann and Kester, 1960). It was dissolved in $90 \%$ ethanol before adding distilled water to make the require strength. However, Hydrogen peroxide $\left(\mathrm{H}_{2} \mathrm{O}_{2}\right)$ at $3.5 \%$ was prepared by take $116.7 \mathrm{ml}$ of $\left(\mathrm{H}_{2} \mathrm{O}_{2}\right)$ and completed to $1000 \mathrm{ml}$ by the addition of distilled water. Vitamin $\mathrm{B}_{12}\left(\mathrm{~V}_{\mathrm{B} 12}\right)$ at $24 \mathrm{mg} / \mathrm{L}$ was prepared by take $24 \mathrm{mg}$ in $1000 \mathrm{ml}$ distilled water.

Cutting plantation: The treated wounded and non-wounded cuttings along with the untreated control ones (dipped in distilled water for 30 second) were planted in well prepared black polyethylene bags $30 \mathrm{~cm}$ in diameter at a depth of $5-6 \mathrm{~cm}$. The bags contained a mixture of sand and Peatmoss at ratio of $1: 1$ $(\mathrm{v} / \mathrm{v}), 12$ cuttings each. The planted bags were placed on the soil surface in greenhouse at a private nursery equipped with mist irrigation unit and immediately after planting were irrigated. The second irrigation was applied one week later. All other cultural practices were kept uniformly as usual during the research work.

Parameters measured on the planted cuttings: The following parameters were studied during the course of the study in the 2 tested seasons. Buds burst percentage per cutting at 4,6 and 8 weeks from planting date; buds survival percentage per cutting at 8,10 and 12-week-old; number of shoots and leaves per cutting at 1.5-month-old along with rooting percentage, primary roots number, primary root length and secondary roots number per cutting at 3 months from planting date.

Experiment design and layout: The experiment was laid out as randomized complete block design. The total number of treatments amounted to 14 treatments. Each treatment was replicated three times, 12 cuttings each.

Data regarding the tested parameters were recorded and subjected to statistical analysis. Means for various treatments were compared using "Duncans Multiple Range Test" (Duncan, 1955).

\section{RESULTS AND DISCUSSION}

Guava trees are one of fruit species that their cuttings have never been rooted, or rooted only rarely and meager amounts, dispite great efforts and much research (Luis et al., 1986). There is convenience evidence that certain natural and synthetic root-induced hormones chemical are essential for root development. The great demand for true to type guava plants, vegetative propagation through cuttings has got the attention of many workers. 
Samaan, L. G. et al.

To overcome some of the inherent difficulties encountered by the cuttings to root, the applied growth and root promoting regulators may be helpful in that respect. Recent investigations in this subject proved that it can be successfully propagated guava plants by cuttings (Reddy and Singh, 1988; Rehman et al., 1990; Mukhtar et al., 1998; Wahab et al., 2001; Ayaz et al., 2004 and Tahseen-Ullah et al., 2005). Therefore, the present research was designed to provide further information on finding out the rooting ability of hardwood stem cuttings of guava by the application of certain growth and root promoters, however one of them is used for the first time $\left(V_{B 12}\right)$ in that respect. According to the great similarity among the data of the 2 tested seasons, the obtained results will be explained as an average of both seasons of the study.

\section{Buds burst and survival percentages per cutting}

This part of study was carried out on the treated non-wounded and wounded cuttings along with the untreated control ones. The results on cuttings at 8-week-old for buds burst $\%$ and at 12-week-old for buds survival $\%$ were considered only to be the net results at the end of this study. It is evident from the obtained results in Tables (1\&2) and illustrated in Figure (1) that the various growth and root promoters had a significant effect on these 2 parameters.

Maximum buds burst \% per cutting was recorded in wounded hardwood cuttings pre-planting treated with dipping in $\mathrm{H}_{2} \mathrm{O}_{2}$ at $3.5 \%$ and in IBA at $4000 \mathrm{ppm}\left(\mathrm{T}_{12}\right)$ with an average percentage of $81.52 \%$ while, the minimum average was resulted in cuttings treated with dipping in $\mathrm{H}_{2} \mathrm{O}_{2}$ at $3.5 \%$ and in $\mathrm{V}_{\mathrm{B} 12}$ at $24 \mathrm{mg} / \mathrm{L}\left(\mathrm{T}_{13}\right)$ with the average value of $62.99 \%$. The corresponding averages in non-wounded cuttings in the same tables were $72.65 \%$ and $52.00 \%$. The former maximum percentage was resulted in cuttings of the treatment included dipping in $\mathrm{H}_{2} \mathrm{O}_{2}$ at $3.5 \%$ only $\left(\mathrm{T}_{3}\right)$, whereas the later minimum average was in cuttings dipped in IBA at 4000 ppm and in $\mathrm{V}_{\mathrm{B} 12}$ at $24 \mathrm{mg} / \mathrm{L}\left(\mathrm{T}_{7}\right)$.

As for buds survival percentage per wounded cuttings, it was found that the effective treatment to give maximum percentage was " $\mathrm{T}_{12}$ " (dipping in $\mathrm{H}_{2} \mathrm{O}_{2}$ at $3.5 \%$ and in IBA at $4000 \mathrm{ppm}$ ) with an average percentage of $62.83 \%$. Minimum percentage was in cuttings of the treatment of dipping in $\mathrm{H}_{2} \mathrm{O}_{2}$ at $3.5 \%$ and in $\mathrm{V}_{\mathrm{B} 12}$ at $24 \mathrm{mg} / \mathrm{L}\left(\mathrm{T}_{13}\right)$ with an average of $30.42 \%$. The corresponding average values in non-wounded cuttings were $53.05 \%$ (maximum) with the treatment of dipping in $\mathrm{H}_{2} \mathrm{O}_{2}$ at $3.5 \%$ and in IBA at 4000 ppm ( $\mathrm{T}_{5}$ ) and $28.75 \%$ (minimum) with $\mathrm{T}_{7}$ treatment (dipping in $\mathrm{H}_{2} \mathrm{O}_{2}$ and in $\mathrm{V}_{\mathrm{B} 12)}$. It is important to record herein that the untreated control cuttings $\left(\mathrm{T}_{1}\right)$ tabulated the averages of 67.15 and $27.09 \%$ for buds burst and survival percentage, respectively. The percentage of buds survival \% almost was the least if compared with the tested treatments. 
J. of Plant Production, Vol. 1 (2), February, 2010

1

305 
Samaan, L. G. et al.

2

306 


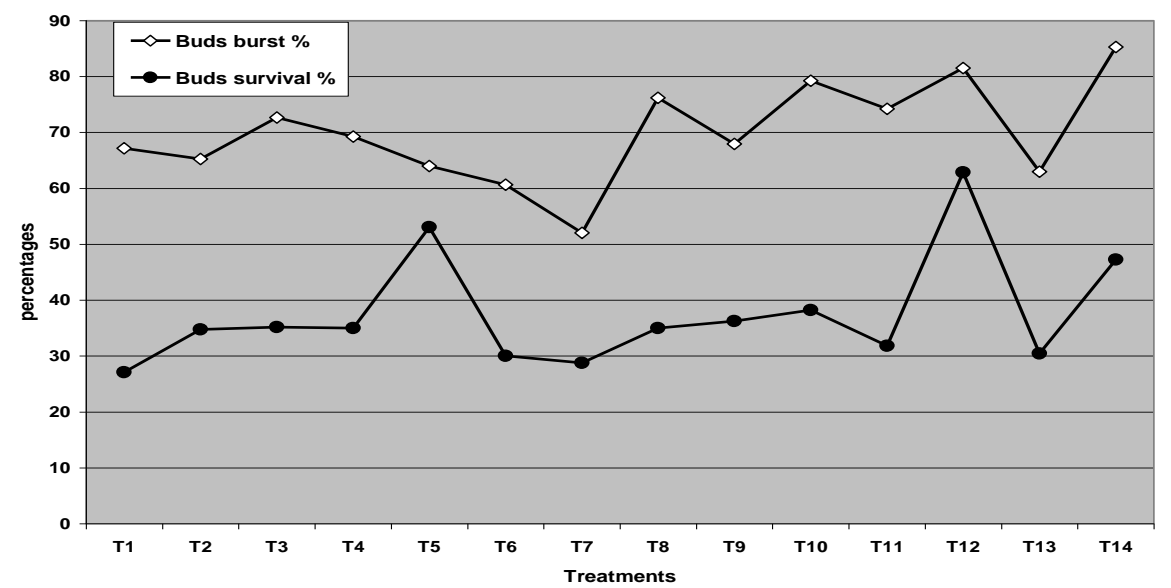

Figure (1): Diagram showing effect of various growth and root promoting regulators along with wounding process on buds burst percentage at 8 -week-old and buds survival at 12-week-old from planting date per cutting of guava stem hardwood cuttings as an average of 2008 and 2009 seasons.

\section{Number of shoots and leaves per cutting}

The concerned results in Table (3) are evidence that the various tested growth and root promoting regulators along with wounding process had obvious effects on shoots and leaves number/cutting at 1.5-month-old. Pre-planting wounding process at the basal portion of hardwood cuttings appeared to be an important factor to increase these 2 morphological characteristics. So, numbers tabulated for the treated wounded cuttings ( $T_{8-}$ $\mathrm{T}_{14}$ ) were significantly higher than those of the treated non-wounded cuttings $\left(\mathrm{T}_{2}-\mathrm{T}_{7}\right)$. The average values of the former group of treatments were ranged from 1.55 to 3.43 shoots/cutting and from 1.68 to 2.75 shoots/cutting. The corresponding average values of the later group of treatments were ranged from 1.68 to 2.55 shoots/cutting and from 2.68 to 4.89 leaves/cutting.

Maximum number of shoots and leaves/cutting was resulted in hardwood wounded cuttings pre-planting dipped in $\mathrm{H}_{2} \mathrm{O}_{2}$ at $3.5 \%$ and in IBA at $4000 \mathrm{ppm}\left(\mathrm{T}_{12}\right)$ with the average values of 3.43 shoots/cutting and 5.75 leaves/cutting. The next higher effect was in cuttings of the treatment " $\mathrm{T}_{14}$ " with the average values of 2.62 shoots/cutting and 5.52 leaves/cutting. Otherwise, the minimum number of shoots/cutting was observed on wounded cuttings of the treatment " $\mathrm{T}_{13}$ " (dipping in $\mathrm{H}_{2} \mathrm{O}_{2}$ and in $\mathrm{V}_{\mathrm{B} 12}$ ) with an average value of 1.55 shoots/cutting, whereas minimum leaves number/cutting (1.98 leaves) was in cuttings of " $\mathrm{T}_{11}$ " treatment (dipping in $\mathrm{V}_{\mathrm{B} 12}$ at $24 \mathrm{mg} / \mathrm{L}$ ). Both wounded and non-wounded cuttings at 1.5 -month-old were counted numbers almost higher than the control ones ( 0.9 shoot and 1.92 leaves per cutting).

The results of the previous four parameters if compared in relation to the effect of tested treatments on wounded and non-wounded cuttings 
strongly pointed to the treatment of wounding process followed by dipping in $\mathrm{H}_{2} \mathrm{O}_{2}$ at $3.5 \%$ and in IBA at $4000 \mathrm{ppm}$ for 30 second each ( $\left.\mathrm{T}_{12}\right)$ as the best treatment to record significantly maximum buds burst and survival percentages as well as shoots and leaves number per cutting. Such super effect of " $\mathrm{T}_{12}$ " treatment can be attributed to the observation on cuttings which are demonstrated that wounding procedure created the greater destruction of basal stem tissues often resulted in rooting above the wounded portion and rotting occurred in the wounded zone. Therefore, the interaction treatment of wounding process followed by dipping in $\mathrm{H}_{2} \mathrm{O}_{2}$ and in IBA was the best to give cuttings had these highest characteristics indicated above. The superiority of " $\mathrm{T}_{12}$ " treatment is also in harmony with the explanations previously reported in certain studies described the reason of wounding process and the applied growth and root promoter effects. They attributed that not fore a direct effect on sprouting percentage, but they are responsible for inducing roots and strong food materials (carbohydrates) in the cutting provide sufficient amount of food for bud sprouting. However, at same latter stages after development of roots the auxin may have indirect effect on the sprouting which needs to be explored (Bleasdale, 1984; Mitra and Bose, 1990). In the same line, Tahir et al., (1998) who worked with hardwood stem cuttings of guava attributed the production of number of shoots and leaves per cutting to the fact that higher amount of carbohydrates were accumulated in hardwood cuttings as compared with other types which helped a lot in sprouting. Better sprouting by hardwood cuttings also may be on account of an accumulation of endogenous growth promoters in the tissue of the treated cuttings.

Table (3): Effect of various growth and root promoting regulators along with wounding process on shoots and leaves average number per cutting of guava stem hardwood cuttings at 1.5 months from planting date in 2008 and 2009 Seasons.

\begin{tabular}{|c|c|c|c|c|c|c|c|}
\hline \multirow[b]{2}{*}{ Cutting Treatments } & \multirow[t]{2}{*}{ Symbol } & \multicolumn{3}{|c|}{ shoots number per cutting } & \multicolumn{3}{|c|}{ leaves number per cutting } \\
\hline & & 2008 & 2009 & Aver. & 2008 & 2009 & Aver. \\
\hline \multicolumn{8}{|c|}{ Non-wounding } \\
\hline Dipping in water & $\mathrm{T}_{1}$ & $1.00 \mathrm{~g}^{*}$ & $0.80 \mathrm{~g}$ & $0.9 \mathrm{~h}$ & $2.00 \mathrm{~g}$ & $1.83 \mathrm{i}$ & $1.92 \mathrm{~h}$ \\
\hline Dipping in IBA & $\mathrm{T}_{2}$ & $1.94 \mathrm{~d}$ & $1.93 \mathrm{de}$ & 1.94de & $3.50 \mathrm{e}$ & 3.90 ef & 3.70 ef \\
\hline Dipping in $\mathrm{H}_{2} \mathrm{O}_{2}$ & $\mathrm{~T}_{3}$ & $2.27 \mathrm{c}$ & $2.29 \mathrm{c}$ & $2.28 \mathrm{c}$ & $3.97 \mathrm{de}$ & 3.90 ef & $3.94 \mathrm{de}$ \\
\hline Dipping in $\mathrm{V}_{\mathrm{B} 12}$ & $\mathrm{~T}_{4}$ & $2.06 \mathrm{~d}$ & $2.07 \mathrm{~cd}$ & $2.07 \mathrm{~d}$ & $3.34 \mathrm{e}$ & $3.28 \mathrm{fg}$ & $3.31 \mathrm{f}$ \\
\hline Dipping in $\left(\mathrm{H}_{2} \mathrm{O}_{2}+\mathrm{IBA}\right)$ & $\mathrm{T}_{5}$ & $2.50 \mathrm{~b}$ & $2.59 \mathrm{~b}$ & $2.55 \mathrm{~b}$ & $4.88 \mathrm{bc}$ & $4.90 \mathrm{~cd}$ & $4.89 \mathrm{bc}$ \\
\hline Dipping in $\left(\mathrm{H}_{2} \mathrm{O}_{2}+\mathrm{V}_{\mathrm{B} 12}\right)$ & $\mathrm{T}_{6}$ & $1.79 \mathrm{e}$ & 1.77 ef & 1.78 ef & $4.00 \mathrm{de}$ & 3.99 ef & $4.00 \mathrm{de}$ \\
\hline Dipping in $\left(\mathrm{IBA}+\mathrm{V}_{\mathrm{B} 12}\right)$ & $\mathrm{T}_{7}$ & 1.67 ef & $1.69 \mathrm{f}$ & $1.68 \mathrm{fg}$ & $2.68 \mathrm{f}$ & $2.67 \mathrm{gh}$ & $2.68 \mathrm{~g}$ \\
\hline \multicolumn{8}{|c|}{ Wounding } \\
\hline Wounding only & $\mathrm{T}_{8}$ & $2.05 \mathrm{~d}$ & $2.07 \mathrm{~cd}$ & $2.06 \mathrm{~d}$ & $5.55 \mathrm{ab}$ & $5.95 \mathrm{a}$ & $5.75 \mathrm{a}$ \\
\hline Wounding + IBA & $\mathrm{T}_{9}$ & $2.63 \mathrm{~b}$ & $2.60 \mathrm{~b}$ & $2.62 \mathrm{~b}$ & $4.52 \mathrm{~cd}$ & $4.39 \mathrm{de}$ & $4.46 \mathrm{~cd}$ \\
\hline Wounding $+\mathrm{H}_{2} \mathrm{O}_{2}$ & $\mathrm{~T}_{10}$ & $2.47 \mathrm{~b}$ & $2.52 \mathrm{~b}$ & $2.50 \mathrm{~b}$ & $5.30 \mathrm{ab}$ & $5.08 b-d$ & $5.19 a b$ \\
\hline Wounding $+\mathrm{V}_{\mathrm{B} 12}$ & $\mathrm{~T}_{11}$ & 1.68 ef & 1.70 ef & $1.69 \mathrm{fg}$ & $2.00 \mathrm{~g}$ & $1.95 \mathrm{hi}$ & $1.98 \mathrm{~h}$ \\
\hline Wounding $+\left(\mathrm{H}_{2} \mathrm{O}_{2}+\mathrm{IBA}\right)$ & $\mathrm{T}_{12}$ & $3.42 \mathrm{a}$ & $3.44 \mathrm{a}$ & $3.43 \mathrm{a}$ & $5.71 \mathrm{a}$ & $5.78 \mathrm{ab}$ & $5.75 \mathrm{a}$ \\
\hline Wounding $+\left(\mathrm{H}_{2} \mathrm{O}_{2}+\mathrm{V}_{\mathrm{B} 12}\right)$ & $T_{13}$ & $1.56 \mathrm{f}$ & $1.54 \mathrm{f}$ & $1.55 \mathrm{~g}$ & $2.20 \mathrm{fg}$ & $2.23 \mathrm{hi}$ & $2.22 \mathrm{gh}$ \\
\hline Wounding $+\left(\mathrm{IBA}+\mathrm{V}_{\mathrm{B} 12}\right)$ & $\mathrm{T}_{14}$ & $2.63 \mathrm{~b}$ & $2.61 \mathrm{~b}$ & $2.62 \mathrm{~b}$ & $5.55 \mathrm{ab}$ & $5.49 a-c$ & $5.52 \mathrm{a}$ \\
\hline
\end{tabular}

*Within the column of each characteristic, means sharing one or more

letters are insignificantly differed at $5 \%$

level according to the "Duncan Least Significant Value". 
The positive effect of $\mathrm{H}_{2} \mathrm{O}_{2}$ and IBA at the applied concentration could be acted a synergist with endogenous hormones and hence better sprouting was observed. The more number of shoots with $\mathrm{H}_{2} \mathrm{O}_{2}$ treatment may be due to such chemical inhibits gibberellins biosynthesis, as paclobutrazol doing, caused growth suppression. The suppression in upward growth may enhance lateral growth (Tahseen Ullah et al., 2005). The same investigators working on guava cuttings explained the increased shoots number according to Baloch, (1994) as auxins may be produced in abundance in growing regions, which may enhance the growth in cuttings.

Maximum number of leaves produced by such best treatment may be satisfied with the reason that the response of ability to develop adventitious roots in this type of cuttings is sufficient to significantly produce more roots. More roots number more supply nutrients from the media for the development of leaves. The positive effect of the applied growth promoters in that respect can be explained also as a significant effect on increasing the leaves number which is one of the production sites of natural auxins in the plant beside the main activities of photosynthesis and transpiration. The increased roots also may have necessitated the enhanced activity of photosynthesis and other activities carried out in the leaves, which in turn may have resulted in the increase of leaves in the treated cuttings (Wahab et al., 2001).

These above explanations are in line with the results of several studies carried out on guava cuttings and other fruit trees. Such studies on guava cuttings and air layers strongly proved that a higher rooting percentage was resulted by the use of wounding process and/or IBA at certain concentrations (Macdonald, 1986, Dantas et al., 1999; Bhagat et al., 1999; AL-Obeed, 2000 and Abdullah et al., 2006). In the same subject, Bartolini and Fabbri, (1982) and Uzunov, (1987) came to a similar result with peach cuttings given basal treatment with IBA at $1000-4000 \mathrm{ppm}$. Our results in this part of the study are also in conformity with the finding of Hartmann and Kester,(1985) who reported that IBA was helpful to increase sprouting, shoots and leaves number per cutting in guava stem cuttings, Pereira et al.,(1985) found that hardwood cuttings treated with IBA at 3000-5000 ppm gave good results.

\section{Cutting root characteristics}

This part of the present investigation was dealt with four root parameters of a great necessary in the successful application of vegetative propagation through cutting. Such root parameters were measured on the treated wounded and non-wounded cuttings as well as control ones at 3-month-old. The obtained results were presented in Table (4) and illustrated in Figure (2). 
Samaan, L. G. et al.

4 
Fig. 2: Photograph showing the effect of various growth and root promoting regulators along with wounding process on rooting percentage and number of primary roots $\left(T_{5}\right.$ and $\left.T_{12}\right)$ and number of secondary roots $\left(T_{8}\right.$ and $\left.T_{12}\right)$ per hardwood stem cutting of guava cv. Balady at 3 month from planting date.

$\mathrm{T}_{1}=$ Untreated control cuttings.

$\mathrm{T}_{5}=$ Non-wounded cuttings dipping in $\mathrm{H}_{2} \mathrm{O}_{2}$ at $3.5 \%$ and in IBA at 4000 ppm for 30 second each.

$\mathrm{T}_{8}=$ Wounding process only.

$\mathrm{T}_{12}=$ Wounding process + dipping in $\mathrm{H}_{2} \mathrm{O}_{2}$ at $3.5 \%$ and in IBA at $4000 \mathrm{ppm}$ for 30 second each.

1-Rooting percentage: The results in Table (4) revealed that rooting percentage was significantly affected by the tested various growth and root promoting regulators and their interactions with wounding process in the 2 tested seasons. Maximum rooting percentage $(70.67 \%)$ was recorded for hardwood wounded cuttings pre-planting were dipped in $\mathrm{H}_{2} \mathrm{O}_{2}$ at $3.5 \%$ and in IBA at $4000 \mathrm{ppm}\left(\mathrm{T}_{12}\right)$. The next super effect was observed in non-wounded cuttings pre-planting treated with the same growth and root promoters $\left(T_{5}\right)$ with an average percentage of $43.00 \%$. Otherwise, minimum rooting percentage was resulted in the untreated control cuttings, which were in complete failing to root $\left(T_{1}\right)$. 
2- Number of primary roots per cutting: The various growth and root promoting regulators and their interactions with wounding process also indicated a significant effect on this cutting characteristic in the 2 tested seasons. Once more, the highest number of primary roots (24.96 roots/ cutting) was noticed in hardwood wounded cuttings pre-planting subjected to " $\mathrm{T}_{12}$ " treatment. The non-wounded cuttings pre-planting with the same promoters $\left(T_{5}\right)$ came to the next order in that respect with the average value of 16.65 roots/cutting. On the other hand, the untreated control cuttings were also failed to produce primary roots $\left(T_{1}\right)$.

3- Primary root length per cutting: The concerned results in the same table and figure once more confirmed the significant effect of tested treatments on this cutting root characteristic in the 2 tested seasons. The longer primary roots $(9.86 \mathrm{~cm})$ were resulted in hardwood non-wounded cuttings pre-planting treated with dipping in IBA at $4000 \mathrm{ppm}$ and in $\mathrm{V}_{\mathrm{B} 12}$ at $24 \mathrm{mg} / \mathrm{L}$ for 30 second each $\left(T_{7}\right)$. While, the wounded cuttings showed a similar effect in the same cuttings under " $\mathrm{T}_{12}$ " treatment with the average primary root length of $8.38 \mathrm{~cm}$.

4- Secondary roots number per cutting: It is evident from the concerned data that hardwood cuttings pre-planting subjected to wounding process only (T8) produced significantly the highest number of secondary roots in both tested seasons with an average value of 11.34 roots/cutting. The next super effect was observed in wounded cuttings received the " $\mathrm{T}_{12}$ " treatment (8.58 roots/cutting). As for, non-wounded hardwood cuttings, the tested treatments succeeded to induce significantly the highest secondary roots number/cutting (5.67 roots) with " $\mathrm{T}_{2}$ " treatment (IBA) followed by 4.70 roots/cutting with " $\mathrm{T}_{5}$ " treatment $\left(\mathrm{H}_{2} \mathrm{O}_{2}\right.$ and IBA) and " $\mathrm{T}_{3}$ " $\left(\mathrm{H}_{2} \mathrm{O}_{2}\right)$ treatment (4.42 roots). These average values significantly were lower than the same root promoters interacted with wounding process as indicated above $\left(T_{12}\right)$. These findings greatly supported the significant super effect of wounding process $\left(T_{8}\right)$ and its interaction with "IBA" $\left(\mathrm{T}_{9}\right)$, " $\mathrm{H}_{2} \mathrm{O}_{2}$ " $\left(\mathrm{T}_{10}\right)$ or both $\left(\mathrm{T}_{12}\right)$ to activate the induction of secondary roots in the treated cuttings. Such treatments respectively tabulated the average values of $11.34,7.44,5.71$ and 8.58 roots/cutting.

According to the forecited results of the measured root characteristics, it could be concluded that the applied " $\mathrm{H}_{2} \mathrm{O}_{2}$ ", "IBA" and their interaction with wounding process $\left(\mathrm{T}_{12}\right)$ had the best significant effect on most of these characteristics. Such findings agreed with the results obtained by Hartmann and Hansen (1957) who found that wounding the base of cutting by knife splits in the bark will markedly stimulates adventitious root production. The mode of action was explained by Macdonald,(1986) as the general purpose of wounding process is to stimulate the initiation of roots from cortex and phloem cells by exposing a greater surface area of these cells than is provided by the cut base in an non-wounded cuttings. He added that cells exposed by wounding may take up the hormone solution more readily as well as some water and other growth factors from the rooting medium. The current results also in harmony with those of the study carried out by Testolin et al., (1988) on rooting peach cuttings in relation to wounding and IBA treatments. They found that wounding increased rooting percentage from 46 to $88 \%$ under the best condition. No difference was observed between the tested IBA at 2 concentrations in non-wounded cuttings, but in 
wounded ones the lower level of IBA gave the best results. Remmick and Bilderback, (1993) reported that split wounding is a relatively common practice in England. Because of the potential benefits, this technique could offer for improving the rooting of difficult to root species.

As for the beneficial effect of IBA, it was evidenced in studies designed to describe the scope of clonal propagation of guava and other fruit trees by stem cuttings. Tahir et al., (1998) indicated that hardwood cuttings and IBA solution performed well with respect to various root and shoot developmental characteristics. Dantas et al., (1999) in Brazil studied the effect of dipping cutting in IBA at different concentrations and found an increasing effect to IBA treatments on rooting percentage. In the same line, Wahab et al., (2001) with semi-hardwood cuttings of guava found that the highest number of roots per cutting was recorded in the cuttings treated with IBA at 4000 ppm. More recent, Abdullah et al., (2006) working on guava stem cuttings treated with IBA at various concentration. The highest rooting and survival percentages were observed in cuttings treated with $0.4 \%$ IBA. Maximum number of primary roots was developed in the cuttings treated with $0.8 \%$ IBA followed by $0.4 \%$ and the lowest was in the untreated cuttings.

Concerning the effective use of IBA solution in cuttings of other fruit trees, Erez and Yablowitz,(1981) working on cuttings of various peach cultivars found that dipping cuttings in IBA at $0.1 \%$ or $1000 \mathrm{mg} / \mathrm{L}$ rooted best with different rooting percentages depending on rooting bed-temperature, taking time and the tested cultivar. Bartolini and Fabbri, (1982) came to a similar results with peach cuttings given basal treatment with 3000 ppm IBA. Also, Silveira et al., (2004) with the objective to propagate avocados vegetatively by means of stem cuttings. Root formation was greatly increased by immersing cuttings in $2000 \mathrm{mg} / \mathrm{L}^{-1}$ IBA for 10 seconds.

The great effect of " $T_{12}$ " treatment on root characteristics is greatly supported the results obtained and discussed on the best effect of such treatment on buds burst and survival percentages (Table 1\&2) and both shoots and leaves per cutting (Table 3 ) as these super effects were attributed indirectly to inducing adventitious roots. The roots once formed take up nutrients from the soil and supply to upper portion for intermediate use and to activate photosynthesis and other activities. This is why the shoots and leaves of successful cuttings remained intact and also started fresh growth. It is a point of important to record herein the reason of applied IBA at 4000 ppm in the present research. This was based on previous studies indicated almost the superiority of this concentration (Uzunov, 1987; Dantas et al., 1999 and Wahab et al., 2001). Moreover, it was in harmony with the results of Bhagat et al., (1999) who reported that the treatment with IBA at $4500 \mathrm{ppm}$ resulted in the highest percentage of rooting and survival percentages of guava air layers. Abdullah et al., (2006) with guava stem cuttings came to similar results with IBA at $0.4 \%$.

The obtained results in the present study provide the workers in the field of guava propagation an additive support to the applicability and usefulness of the applied treatments on successful propagated guava through hardwood stem cuttings. These successes add on easy, quick and economical method of vegetative propagation to avoid segregation progeny 
in the orchard with diversified fruiting behavior and quality and, quest for true to type guava trees which has increased. Keeping in view the importance of guava propagation from cuttings and the role of growth and root promoting regulators in inducing the roots in cuttings. The most effective treatment among the tested ones was that of pre-planting wounded cuttings just before inserting in planting medium dipped in $\mathrm{H}_{2} \mathrm{O}_{2}$ solution at $3.5 \%$ followed in IBA solution at $4000 \mathrm{ppm}$ for 30 second each $\left(T_{12}\right)$. Therefore, it is the recommended pre-planting treatment among the tested ones for hardwood stem cuttings of guava cv. Balady which are known as difficult to root fruit species. The successful application of this treatment is in turn enhance the nursery operation in that respect.

Further studies are required to throw some light on the response of endogenous promoters and hormones as well as other biochemical constituents in the tissues of cutting especially in the basal portion as a result of the applied exogenous growth and root promoting regulators.

\section{REFERENCES}

Abdullah, A.T.M.; Hossain, M.A.; Bhuiyan, M.K. (2006). Clonal propagation of guava (Psidium guajava L.) by stem cutting from mature stock plants. Journal of Forestry Research. 17(4): 301-304.

Ahmad, R. (1961). Some studies on the propagational methods in guava in West Pakistan. M.Sc. Thesis, Agric. Univ., Faisalabad.

Al-Obeed, R.S. (2000). The effect of growth regulators, phenolic compounds and time of propagation on the rooting of guava stem cuttings. Alexandria journal of Agriculture research, 45(2): 189-199.

Ayaz, M., Hussain, S.A. and Ali, N. (2004). Effect of paclobutrazol concentration and dipping period on rooting of soft wood cuttings of guava (Psidium guajava L.).Pakistan Journal of Biological Science 7 (1): 28-31.

Baloch, A.F. (1994). Phases of Plant Growth In: Malik, M.N. Horticulture. $2^{\text {nd }}$ Edn., National Book Foundation, Islamabad, Pakistan.

Bartolini, G. and Fabbri, A. (1982). Double soaking to increase the survival of rooted peach cuttings. Rivista della Ortoflorofrutticoltura Italiana, 66(4): 323-329.

Bhagat, B.K.; Jain, B.P. and Singh, C. (1999). Success and survival of intergeneric grafts in guava (Psidium guajava L.). Journal of Research, Birsa Agricultural University, India. 11(1): 79-81.

Bleasdale, J.K.A. (1984). Plant Physiology in Relation to Horticulture $2^{\text {nd }}$ Ed. The Mac Millan press Ltd. London, pp: 92-95.

Dantas, A.C. de M.; Dutra, L.F. and Kesten, E. (1999). Influence of Indole butyric acid and ethephon on rooting of stem cuttings of guava (Psidium guajava L.). Revista Cientifica Rural, Brazil, 4(2): 29-33.

Debnath, G.C and Maiti,S.C (1990). Effect of growth regulators on rooting of soft wood cutting of guava under mist .Haryana Journal of Horticultural Scinences, 19:79-85.

Duncan, B.D. (1955). Multiple range and multiple tests. Biometrics, 11: 1-42. 
El-Baradi, T.A. (1975). "Guava", Abst. on Trop. Agr. 1 (3), 9-16.

Erez, A., and Yablowitz, Z. (1981). Rooting of peach hardwood cuttings for the meadow orchard. Science Horticulturae, 15(2): 137-144.

Hartmann, H.T. and Hansen, C.J. (1957). Tree fruit cuttings propagated (vegetative propagation of softwood cuttings of certain tree fruit rootstocks achieved by chemical and mist treatments). California Agriculture, July.

Hartmann, H.T. and Kester, D.E. (1985). Plant propagation, principles and practices $3^{\text {rd }}$. Ed . Englewood Cliffs, N.J. Prentic Hall Inc. New York: 481.

Hartmann, H.T. and Kester, D.E. (1960). Plant propagation principles and practice. Hall Inc. New York, pp: 481.

Hartmann, H.T.; Flocker, W.J. and Korfranek, A.M. (1981). Plant Science : Growth, Development and Utilization of cultivated plants prentice - Hall In C. Eaglewood cliffs. New Jersey, 07632.

Luis, A.S.; Raul, S. and Rodrigo, T.J.C. (1986). Vegetative propagation of guava by different types of cuttings. Hort. Sci., 21: 663.

Macdonald, B. (1986). Practical woody plant propagation for nursery growers. Timber Press, Portland, OR. 669 p.

Mitra, S.K. and Bose, T.K. (1990). Fruits Tropical and Sub-Tropical Guava Naya Prokash, 206 Bidhan Sarani, Calcutta, 700006 : 280-301.

Mukhtar, A.; Iftikhar, A.; laghari, M.H. and Hidayatullah (1998). Effect of growth regulators on rooting in soft wood cuttings of guava under mist condition. Sarhad J. Agric. Res., 14: 423-425.

Pereira, F.M.; Oiloli, A.A.P. and Banzatto, D.A. (1985). Rooting of different types of guava leafy cuttings under mist. Cientifica, 11: 239-244.

Prakash, D.P.; Narayana Swamy, P. and Sondur, S.N. (2002). Analysis of molecular diversity in guava using RAPD markers Journal of Horticultural Science and Biotechnology, 77, 287- 93.

Reddy, K.M. and Singh, R.N. (1988). Efficacy of plastic house in propagation of guava (Psidium guajava L.) through hardwood cuttings. Indian J. Agric. Sci., 58: 81-82.

Rehman H.U.; Khan, M.A.; Khokhar, K.M. and Lazhari, M.H. (1991). Effect of season on rooting ability of tip cuttings of guava treated with paclobutrazol. Ind. J. Agri. Sci., 61: 464-466.

Remmick, M.D. and Bilderback, T.E. (1993). Split wounding of stem cuttings. SNA Research Conference. Vol. 38-1993 (USA).

Silveira, S.V.; Dutra, S.P.V. and Carlos, K.O. (2004). Vegetative propagation of avocado, by stem cuttings. Rev. Bras. Frutic. 26(1): 191-192.

Tahir, F.M.; Pervez, M.A. and Ahmad, R. (1998). Effect of growth Regulators on rooting performance of stem cutting in guava (Psidium guajava L.). Pakistan Journal of Biological sciences. Pakistan, 1(2): 132-133.

Tahseen Ullah, T.; Wazir, L.U.; Ahmad, M.; Analoui and Khan, M.V. (2005). A Break through in guava (Psidium guajava L.) propagation from cutting. Asian J. of Plants Science, 4(3): 238-243.

Testolin, R.; Avanzato, D. and Couvillon, A.G. (1988). Rooting peach by mallet cuttings. Acta. Horticulturae, 227: 224-229. 


\section{Samaan, L. G. et al.}

Uzunov, A. (1987). Effect of growth regulator treatment on GF655/2 rootstock propagation by hardwood cuttings. Rastenier dni Nauki, 24(7): 62-66 (Bulgaria).

Wahab, F.; Nabil, G.; Ali, N. and Shan, M. (2001). Rooting response of semihardwood cuttings of guava (Psidium guajava L.) to various concentrations of different auxins. Online Journal of Biological Sciences, 1(4): 184-187.

\section{استجابة العقل الساقية الخشبية للجوافة لمنظمات منشطة للتجذير والنمو مختلفة

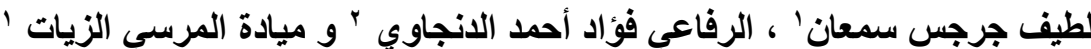

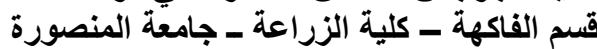 قسم الفاكهة ـ كلية الزراعة ـ فرع دمياط ـ جامعة المنصورة}

يهذف البحث الحالي إلى در اسة تأثير ثلاث مو اد منظمة لاستحثناث التجذير و النمو هي:-

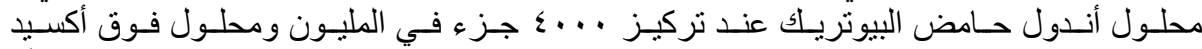

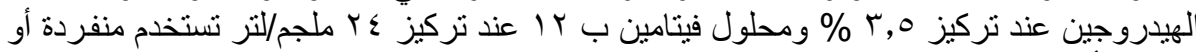

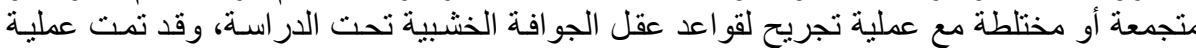

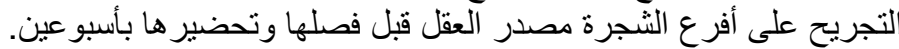

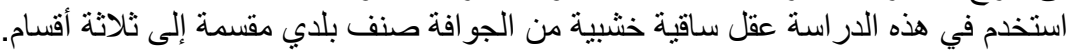

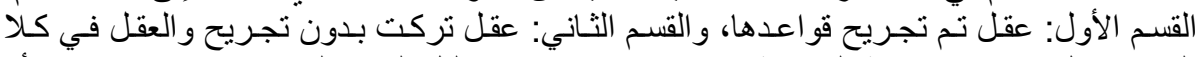

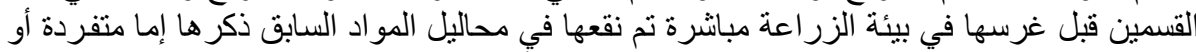

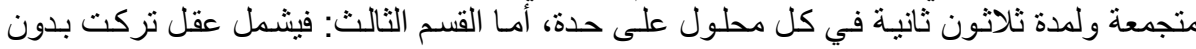

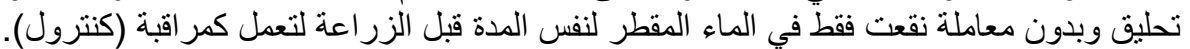

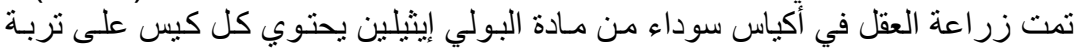

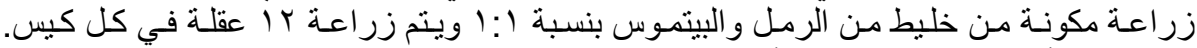

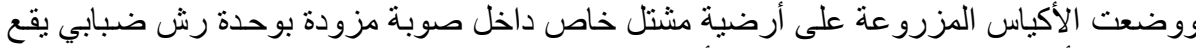

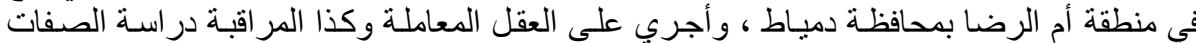

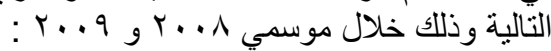

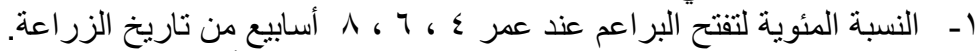

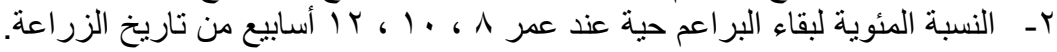

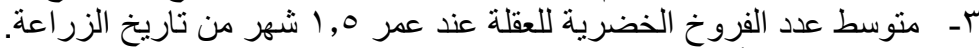

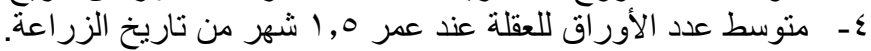

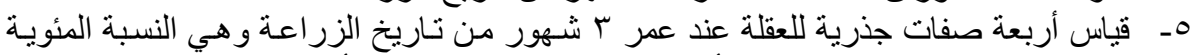

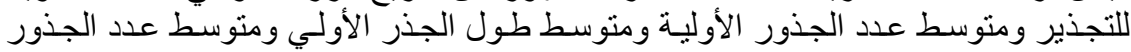
الثانوية.

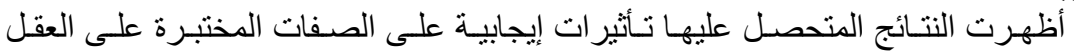

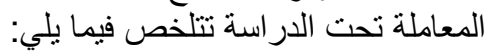

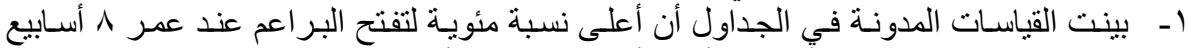

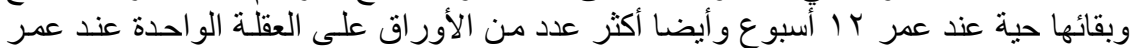

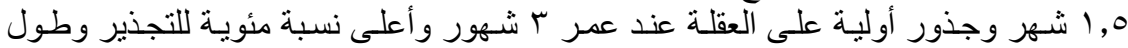

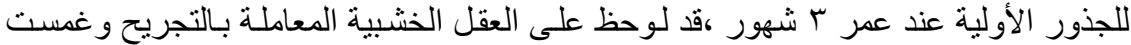

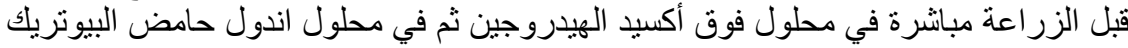

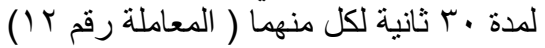




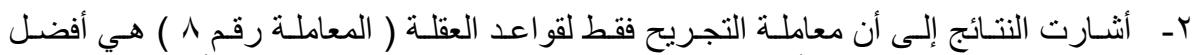

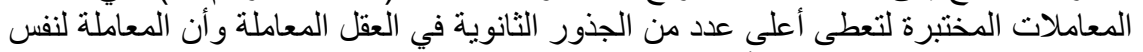

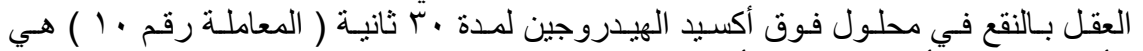

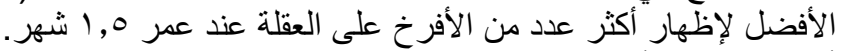

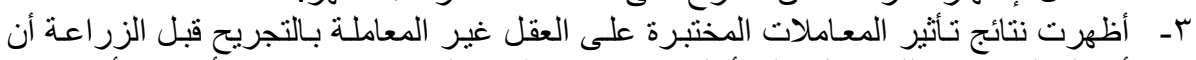

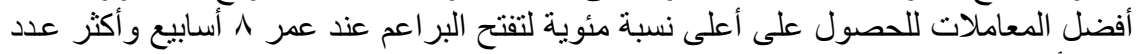

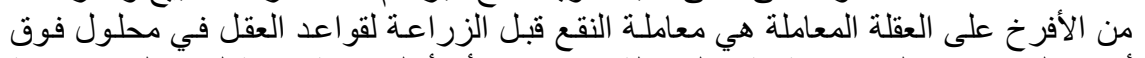

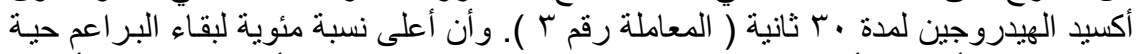

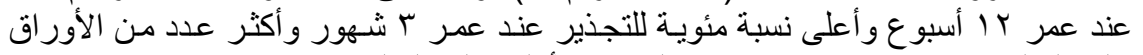

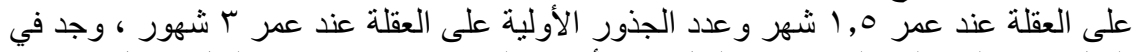

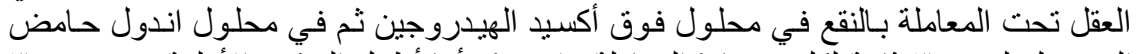

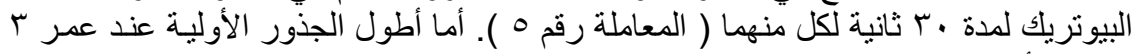

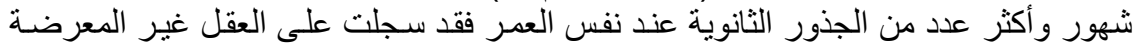

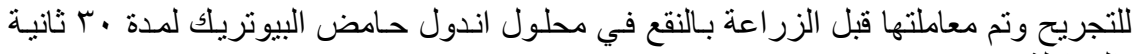

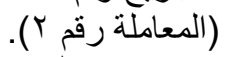

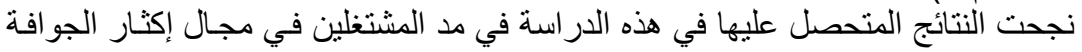

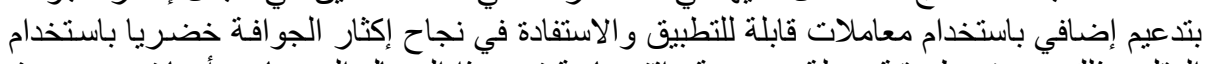

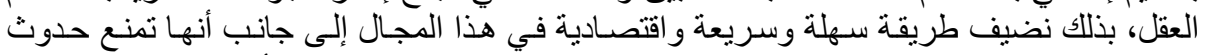

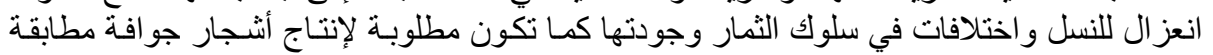

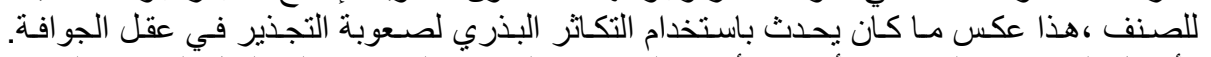

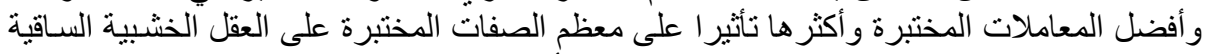

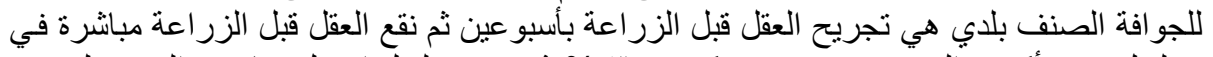

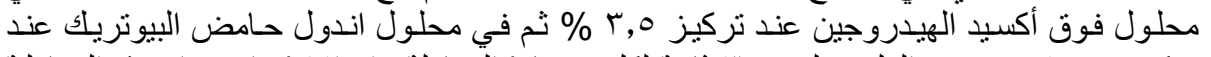

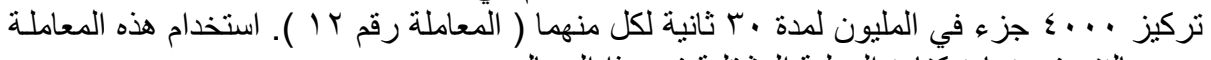

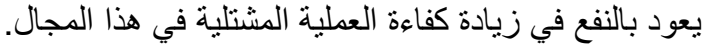

كلية الزراعة - جامعة المنصورة كلية الزراعة - جامعة أسيوط 
Samaan, L. G. et al. 
Table (1): Effect of various growth and root promoting regulators along with wounding process on buds burst percentage per cutting of guava stem hardwood cuttings at 4-, 6- and 8-week-old from planting date in 2008 and 2009 Seasons.

\begin{tabular}{|c|c|c|c|c|c|c|c|c|c|c|}
\hline \multirow[b]{2}{*}{ Cutting Treatments } & \multirow{2}{*}{ Symbol } & \multicolumn{3}{|c|}{ Buds burst $\%$ at 4 Weeks } & \multicolumn{3}{|c|}{ Buds burst $\%$ at 6 Weeks } & \multicolumn{3}{|c|}{ Buds burst $\%$ at 8 Weeks } \\
\hline & & 2008 & 2009 & Average & 2008 & 2009 & Average & 2008 & 2009 & Average \\
\hline \multicolumn{11}{|c|}{ Non-wounding } \\
\hline Dipping in water & $T_{1}$ & $79.30 \mathrm{bc}^{*}$ & $78.02 \mathrm{bc}$ & $78.66 \mathrm{c}$ & $64.00 \mathrm{~d}-\mathrm{f}$ & $67.67 \mathrm{~d}$ & 65.84 ef & $68.47 d-f$ & $65.83 \mathrm{fg}$ & $67.15 \mathrm{gh}$ \\
\hline Dipping in IBA & $T_{2}$ & $8.83 \mathrm{~d}$ & $68.06 \mathrm{de}$ & $68.45 \mathrm{~d}$ & $83.30 \mathrm{ab}$ & $84.50 \mathrm{ab}$ & $83.90 \mathrm{ab}$ & 65.63 ef & $64.85 \mathrm{fg}$ & $65.24 \mathrm{~g}-\mathrm{i}$ \\
\hline Dipping in $\mathrm{H}_{2} \mathrm{O}_{2}$ & $T_{3}$ & $54.03 \mathrm{ef}$ & $4.61 \mathrm{fg}$ & $54.32 \mathrm{f}$ & $79.77 \mathrm{bc}$ & $70 \mathrm{bc}$ & $4 \mathrm{bc}$ & $73.29 \mathrm{~cd}$ & $72.00 \mathrm{c}-\mathrm{e}$ & $72.65 \mathrm{~d}-\mathrm{f}$ \\
\hline Dipping in $\mathrm{V}_{\mathrm{B} 12}$ & $\mathrm{~T}_{4}$ & $88.05 a$ & $86.90 \mathrm{ab}$ & $87.48 \mathrm{ab}$ & $72.67 \mathrm{~cd}$ & $73.67 \mathrm{~cd}$ & $73.17 \mathrm{~cd}$ & $69.67 \mathrm{de}$ & 38.83d-f & $69.25 \mathrm{e}-\mathrm{g}$ \\
\hline Dipping in $\left(\mathrm{H}_{2} \mathrm{O}_{2}+\right.$ IBA $)$ & $T_{5}$ & $81.89 a-c$ & $82.51 a-c$ & $82.20 \mathrm{bc}$ & $86.33 \mathrm{ab}$ & $87.00 \mathrm{ab}$ & $86.67 \mathrm{a}$ & 63.08 ef & $64.86 \mathrm{fg}$ & $63.97 \mathrm{~g}-\mathrm{i}$ \\
\hline Dipp & $T_{6}$ & & & $2 \mathrm{~g}$ & & & & $61.22 \mathrm{f}$ & & $60.61 \mathrm{i}$ \\
\hline Dipping & $T$ & $33 \mathrm{fg}$ & & $47.92 \mathrm{~g}$ & $54.10 \mathrm{~g}$ & & $5 \mathrm{~g}$ & $50.67 \mathrm{~g}$ & $3 \mathrm{~h}$ & $2.00 \mathrm{j}$ \\
\hline \multicolumn{11}{|c|}{ Woundir } \\
\hline & $T_{8}$ & $35 \mathrm{c}$ & & $76.12 \mathrm{c}$ & $62.61 \mathrm{e}-\mathrm{g}$ & & $2 \mathrm{f}$ & $77.65 \mathrm{bc}$ & $74.78 \mathrm{bc}$ & $76.22 \mathrm{~cd}$ \\
\hline Wou & $T_{9}$ & $30 \mathrm{c}$ & & $\mathrm{c}$ & & & $8 \mathrm{a}$ & $68.22 d-f$ & 6 ef & $67.94 f-h$ \\
\hline Wounding $+\mathrm{H}_{2} \mathrm{O}_{2}$ & $T_{10}$ & $85.00 \mathrm{ab}$ & $84.82 \mathrm{a}-\mathrm{c}$ & $84.91 \mathrm{ab}$ & $86.33 \mathrm{ab}$ & $87.67 a b$ & $87.00 \mathrm{a}$ & $78.50 a-c$ & $80.01 \mathrm{ab}$ & $79.26 \mathrm{bc}$ \\
\hline Wounding + $\mathrm{V}_{\mathrm{B} 12}$ & $T_{11}$ & $55.67 \mathrm{ef}$ & $55.44 \mathrm{fg}$ & 55.56 ef & $62.33 \mathrm{fg}$ & $63.00 \mathrm{de}$ & $62.67 \mathrm{f}$ & $74.33 \mathrm{~cd}$ & $74.08 \mathrm{~cd}$ & $74.21 \mathrm{c}-\mathrm{e}$ \\
\hline & $T_{12}$ & $88.18 \mathrm{a}$ & & $88.84 \mathrm{a}$ & $90.03 \mathrm{a}$ & 87. & $88.77 \mathrm{a}$ & $81.73 \mathrm{ab}$ & $81.30 \mathrm{a}$ & $81.52 \mathrm{ab}$ \\
\hline Wou & 1.13 & $33 \mathrm{e}$ & & & 71. & 69. & de & 65.39 ef & $8 \mathrm{~g}$ & $62.99 \mathrm{hi}$ \\
\hline Wounding $+\left(\right.$ IBA $\left.+V_{\mathrm{B} 12}\right)$ & $T_{14}$ & $88.40 \mathrm{a}$ & $86.73 \mathrm{ab}$ & $87.57 \mathrm{ab}$ & $89.00 \mathrm{ab}$ & $91.67 \mathrm{a}$ & $90.34 \mathrm{a}$ & $85.28 \mathrm{a}$ & $85.29 \mathrm{a}$ & $85.29 \mathrm{a}$ \\
\hline
\end{tabular}

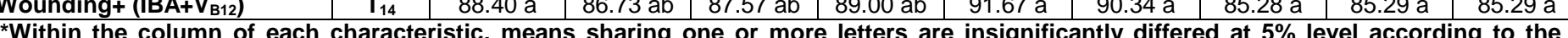

"Duncan Least Significant Value". 
Table (2): Effect of various growth and root promoting regulators along with wounding process on buds survival percentage per cutting of guava stem hardwood cuttings at 8-, 10- and 12-week-old from planting date in 2008 and 2009 Seasons.

\begin{tabular}{|c|c|c|c|c|c|c|c|c|c|c|}
\hline \multirow{2}{*}{ Cutting Treatments } & \multirow{2}{*}{ Symbol } & \multicolumn{3}{|c|}{ Buds survival \% at 8 Weeks } & \multicolumn{3}{|c|}{ Buds survival \% at 10 Weeks } & \multicolumn{3}{|c|}{ Buds survival $\%$ at 12 Weeks } \\
\hline & & 2008 & 2009 & Average & 2008 & 2009 & Average & 2008 & 2009 & Average \\
\hline \multicolumn{11}{|c|}{ Non-wounding } \\
\hline ipping in water & $T_{1}$ & $3.47 d-f^{\star}$ & $5.83 \mathrm{fg}$ & $67.15 \mathrm{gh}$ & $36.11 \mathrm{~d}$ & 35.42 ef & $35.77 \mathrm{~g}$ & $25.00 \mathrm{i}$ & $29.17 \mathrm{~h}$ & $27.09 \mathrm{~h}$ \\
\hline Dipping in IBA & $T_{2}$ & 5.63 ef & $4.85 \mathrm{fg}$ & $65.24 \mathrm{~g}-\mathrm{i}$ & $52.92 \mathrm{bc}$ & $50.29 \mathrm{bc}$ & $1.61 \mathrm{de}$ & $33.86 \mathrm{~d}-\mathrm{f}$ & $35.58 \mathrm{~d}-\mathrm{f}$ & $34.72 \mathrm{ef}$ \\
\hline ipping in $\mathrm{H}_{2} \mathrm{O}_{2}$ & $T_{3}$ & $3.29 \mathrm{~cd}$ & $72.00 c-e$ & $72.65 d-f$ & $59.25 \mathrm{ab}$ & $57.50 \mathrm{ab}$ & $58.38 \mathrm{ab}$ & $36.08 \mathrm{de}$ & $34.19 \mathrm{e}-\mathrm{g}$ & $35.14 d-\mathrm{f}$ \\
\hline ipping in $V_{B 12}$ & $\mathrm{~T}_{4}$ & $9.67 \mathrm{de}$ & $68.83 \mathrm{~d}-\mathrm{f}$ & $69.25 \mathrm{e}-\mathrm{g}$ & $47.64 \mathrm{c}$ & $47.08 \mathrm{~cd}$ & $47.36 \mathrm{e}$ & $34.17 \mathrm{~d}-\mathrm{f}$ & $35.83 d-f$ & $35.00 \mathrm{~d}-\mathrm{t}$ \\
\hline ipping in $\left(\mathrm{H}_{2} \mathrm{O}_{2}\right.$ & $T_{5}$ & ef & $4.86 \mathrm{fg}$ & $g-i$ & $\mathrm{bc}$ & Ba-c & $\mathrm{cd}$ & $54.17 \mathrm{~b}$ & $2 \mathrm{~b}$ & $5 \mathrm{~b}$ \\
\hline Dipping & $T_{6}$ & $22 f$ & $.00 \mathrm{~g}$ & $60.61 \mathrm{i}$ & 37 & $34.17 \mathrm{f}$ & $4 \mathrm{~g}$ & $29.17 \mathrm{gh}$ & $30.83 \mathrm{gh}$ & $30.00 \mathrm{gh}$ \\
\hline Dipping in (IBA+ $\left.V_{B 12}\right)$ & $T_{7}$ & $50.67 \mathrm{~g}$ & $53.33 \mathrm{~h}$ & $52.00 \mathrm{j}$ & 37 & 35.42 ef & $6 \mathrm{~g}$ & $27.50 \mathrm{hi}$ & $30.00 \mathrm{~h}$ & $28.75 \mathrm{gh}$ \\
\hline \multicolumn{11}{|c|}{ Wounding } \\
\hline Iou & $T_{8}$ & $\mathrm{bc}$ & $74.78 \mathrm{bc}$ & $76.22 \mathrm{~cd}$ & $40.18 d$ & $5 \mathrm{de}$ & $41.42 \mathrm{f}$ & $e-g$ & $\mathrm{de}$ & $35.00 \mathrm{~d}-\mathrm{f}$ \\
\hline Wounding + IBA & $T_{9}$ & $68.22 \mathrm{~d}-\mathrm{f}$ & 67.66 ef & $67.94 f-h$ & $54.86 \mathrm{bc}$ & $53.54 a-c$ & $54.20 \mathrm{~b}-\mathrm{d}$ & $35.00 \mathrm{~d}-\mathrm{f}$ & $37.50 \mathrm{de}$ & $36.25 \mathrm{de}$ \\
\hline Wounding $+\mathrm{H}_{2} \mathrm{O}_{2}$ & $T_{10}$ & $78.50 \mathrm{a}-\mathrm{c}$ & $80.01 \mathrm{ab}$ & $79.26 \mathrm{bc}$ & 52.7 & 53.61a-c & $53.18 \mathrm{~cd}$ & $37.53 \mathrm{~d}$ & $4 \mathrm{~d}$ & $38.24 \mathrm{~d}$ \\
\hline 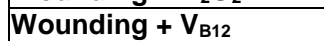 & & $74.33 \mathrm{~cd}$ & $74.08 \mathrm{~cd}$ & & & 41. & $40.49 \mathrm{fg}$ & $31.11 \mathrm{f}-\mathrm{h}$ & of-h & $31.81 \mathrm{fg}$ \\
\hline loun & $T_{12}$ & $81.73 a b$ & $81.30 \mathrm{a}$ & $81.52 a b$ & 65. & $59.67 \mathrm{a}$ & $62.59 \mathrm{a}$ & $64.58 \mathrm{a}$ & $61.08 \mathrm{a}$ & $62.83 \mathrm{a}$ \\
\hline Wounding $+\left(\mathrm{H}_{2} \mathrm{O}_{2}+\mathrm{V}_{\mathrm{B} 12}\right)$ & $T_{13}$ & 65.39 ef & $60.58 \mathrm{~g}$ & $62.99 \mathrm{hi}$ & $35.97 \mathrm{~d}$ & 38.89 ef & $37.43 \mathrm{fg}$ & $29.17 \mathrm{gh}$ & $31.67 \mathrm{gh}$ & $30.42 \mathrm{~g}$ \\
\hline Wounding+(IBA+V $\mathrm{V}_{\mathrm{B} 12)}$ & $T_{14}$ & $85.28 \mathrm{a}$ & $85.29 \mathrm{a}$ & $85.29 \mathrm{a}$ & $59.85 \mathrm{ab}$ & $54.88 \mathrm{ab}$ & $57.37 \mathrm{bc}$ & $48.17 \mathrm{c}$ & $46.33 \mathrm{c}$ & $47.25 \mathrm{c}$ \\
\hline
\end{tabular}

\begin{tabular}{|l|l|l|l|l|l|l|l|l|l} 
& $85.28 \mathrm{a}$ & $85.29 \mathrm{a}$ & $85.29 \mathrm{a}$ & $59.85 \mathrm{ab}$ & $54.88 \mathrm{ab}$ & $57.37 \mathrm{bC}$ & $48.17 \mathrm{C}$ & $46.33 \mathrm{C}$ & $47.25 \mathrm{C}$ \\
\hline
\end{tabular}

(Duncan column of each chan 
Table (4): Effect of various growth and root promoting regulators along with wounding process on root characteristics of guava stem hardwood cuttings after 3 months from planting date in 2008 and 2009 Seasons.

\begin{tabular}{|c|c|c|c|c|c|c|c|c|c|c|c|c|c|}
\hline \multirow{2}{*}{ Cutting Treatments } & \multirow[t]{2}{*}{ Symbol } & \multicolumn{3}{|c|}{ Rooting (\%) } & \multicolumn{3}{|c|}{$\begin{array}{l}\text { Primary roots number } \\
\text { per cutting }\end{array}$} & \multicolumn{3}{|c|}{$\begin{array}{c}\text { Primary roots length per } \\
\text { cutting }(\mathrm{cm})\end{array}$} & \multicolumn{3}{|c|}{$\begin{array}{c}\text { Secondary roots number } \\
\text { per cutting }\end{array}$} \\
\hline & & 2008 & 2009 & Aver. & 2008 & 2009 & Aver. & 2008 & 2009 & Aver. & 2008 & 2009 & Aver. \\
\hline \multicolumn{14}{|c|}{ Non-wounding } \\
\hline Dipping in water & $T_{1}$ & $00.00 \mathrm{~g}^{*}$ & $00.00 \mathrm{j}$ & $00.00 \mathrm{i}$ & $00.00 \mathrm{j}$ & $00.00 \mathrm{i}$ & $00.00 \mathrm{j}$ & $00.00 \mathrm{i}$ & $00.00 \mathrm{i}$ & $00.00 \mathrm{j}$ & $00.00 \mathrm{~h}$ & $00.00 \mathrm{~g}$ & $00.00 \mathrm{~g}$ \\
\hline Dipping in IBA & $T_{2}$ & $14.33 \mathrm{e}$ & $13.33 \mathrm{~h}$ & $13.83 \mathrm{~g}$ & $5.77 \mathrm{gh}$ & $5.57 \mathrm{~g}$ & $5.67 \mathrm{gh}$ & $7.28 \mathrm{c}$ & $6.92 \mathrm{c}$ & $7.10 \mathrm{c}$ & $5.83 \mathrm{e}$ & $5.50 \mathrm{~cd}$ & $5.67 \mathrm{~d}$ \\
\hline Dipping in $\mathrm{H}_{2} \mathrm{O}_{2}$ & $T_{3}$ & $17.00 \mathrm{e}$ & $19.00 \mathrm{f}$ & $18.00 \mathrm{f}$ & $6.63 \mathrm{f}$ & $6.43 \mathrm{f}$ & $6.53 \mathrm{f}$ & $6.59 c-e$ & 6.36c-e & $6.48 \mathrm{c}-\mathrm{e}$ & $3.83 \mathrm{~g}$ & $5.00 \mathrm{de}$ & 4.42ef \\
\hline Dipping in $\mathrm{V}_{\mathrm{B} 12}$ & $T_{4}$ & $16.00 \mathrm{e}$ & $16.23 \mathrm{~g}$ & $16.12 \mathrm{fg}$ & $6.17 \mathrm{fg}$ & $6.43 \mathrm{f}$ & $6.30 \mathrm{f}$ & $5.43 \mathrm{f}$ & $5.47 \mathrm{f}$ & $5.45 \mathrm{~g}$ & $3.92 \mathrm{~g}$ & $3.90 \mathrm{f}$ & $3.91 \mathrm{f}$ \\
\hline Dipping in $\left(\mathrm{H}_{2} \mathrm{O}_{2}+\right.$ IBA $)$ & $T_{5}$ & $42.67 \mathrm{~b}$ & $43.33 \mathrm{~b}$ & $43.00 \mathrm{~b}$ & $16.60 \mathrm{~b}$ & $16.70 \mathrm{~b}$ & $16.65 \mathrm{~b}$ & 5.82ef & 5.72ef & $5.77 \mathrm{fg}$ & $4.67 \mathrm{f}$ & $4.73 \mathrm{e}$ & $4.70 \mathrm{e}$ \\
\hline Dipping in $\left(\mathrm{H}_{2} \mathrm{O}_{2}+\mathrm{V}_{\mathrm{B} 12}\right)$ & $T_{6}$ & $15.67 \mathrm{e}$ & $16.00 \mathrm{~g}$ & $15.84 \mathrm{fg}$ & $5.23 \mathrm{~h}$ & $5.30 \mathrm{~g}$ & $5.27 \mathrm{~h}$ & $2.90 \mathrm{~h}$ & $2.93 \mathrm{~h}$ & $2.92 \mathrm{i}$ & $00.00 \mathrm{~h}$ & $00.00 \mathrm{~g}$ & $00.00 \mathrm{~g}$ \\
\hline Dipping in (IBA+V $\left.V_{B 12}\right)$ & $\mathrm{T}_{7}$ & $06.17 \mathrm{f}$ & $5.93 \mathrm{i}$ & $6.05 \mathrm{~h}$ & $3.77 \mathrm{i}$ & $3.57 \mathrm{~h}$ & $3.67 \mathrm{i}$ & $9.91 \mathrm{a}$ & $9.80 \mathrm{a}$ & $9.86 \mathrm{a}$ & $00.00 \mathrm{~h}$ & $00.00 \mathrm{~g}$ & $00.00 \mathrm{~g}$ \\
\hline \multicolumn{14}{|c|}{ Wounding } \\
\hline Wounding only & $T_{8}$ & $26.67 \mathrm{~d}$ & $27.33 \mathrm{e}$ & $27.00 \mathrm{e}$ & $12.23 \mathrm{e}$ & $\mid 12.27 \mathrm{e}$ & $12.25 \mathrm{e}$ & $6.29 \mathrm{de}$ & \begin{tabular}{|l|}
$6.32 \mathrm{c}-\mathrm{e}$ \\
\end{tabular} & $6.31 \mathrm{~d}-\mathrm{f}$ & $12.00 \mathrm{a}$ & $10.67 \mathrm{a}$ & $11.34 \mathrm{a}$ \\
\hline Wounding + IBA & $T_{9}$ & $35.00 \mathrm{c}$ & $34.44 \mathrm{~d}$ & $34.72 \mathrm{~d}$ & $13.17 \mathrm{~d}$ & $12.83 \mathrm{~d}$ & $13.00 \mathrm{~d}$ & $6.78 \mathrm{~cd}$ & $6.73 \mathrm{~cd}$ & $6.76 \mathrm{~cd}$ & $7.04 \mathrm{~d}$ & $7.83 \mathrm{~b}$ & $7.44 \mathrm{c}$ \\
\hline Wounding $+\mathrm{H}_{2} \mathrm{O}_{2}$ & $T_{10}$ & $35.00 \mathrm{c}$ & $36.00 \mathrm{~cd}$ & $35.50 \mathrm{~cd}$ & $15.60 \mathrm{c}$ & $15.70 \mathrm{c}$ & $15.65 \mathrm{c}$ & $6.55 c-e$ & $6.61 \mathrm{~cd}$ & $6.58 \mathrm{c}-\mathrm{e}$ & $5.43 \mathrm{e}$ & $5.99 \mathrm{c}$ & $5.71 \mathrm{~d}$ \\
\hline Wounding $+V_{B 12}$ & $T_{11}$ & $5.67 \mathrm{f}$ & $5.50 \mathrm{i}$ & $5.59 \mathrm{~h}$ & $3.50 \mathrm{i}$ & $3.50 \mathrm{~h}$ & $3.50 \mathrm{i}$ & $3.67 \mathrm{~g}$ & $3.73 \mathrm{~g}$ & $3.70 \mathrm{~h}$ & $00.00 \mathrm{~h}$ & $00.00 \mathrm{~g}$ & $00.00 \mathrm{~g}$ \\
\hline Wounding $+\left(\mathrm{H}_{2} \mathrm{O}_{2}+\mathrm{IBA}\right)$ & $T_{12}$ & $70.33 \mathrm{a}$ & $71.00 \mathrm{a}$ & $70.67 \mathrm{a}$ & $25.61 \mathrm{a}$ & $24.30 \mathrm{a}$ & $24.96 \mathrm{a}$ & $8.25 \mathrm{~b}$ & $8.50 \mathrm{~b}$ & $8.38 \mathrm{~b}$ & $8.61 \mathrm{~b}$ & $8.55 \mathrm{~b}$ & $8.58 \mathrm{~b}$ \\
\hline Wounding $+\left(\mathrm{H}_{2} \mathrm{O}_{2}+\mathrm{V}_{\mathrm{B} 12}\right)$ & $T_{13}$ & $16.32 \mathrm{e}$ & $16.00 \mathrm{~g}$ & $16.16 \mathrm{fg}$ & $6.07 \mathrm{fg}$ & $6.23 \mathrm{f}$ & $6.15 \mathrm{fg}$ & 3.59gh & $3.82 \mathrm{~g}$ & $3.71 \mathrm{~h}$ & $00.00 \mathrm{~h}$ & $00.00 \mathrm{~g}$ & $00.00 \mathrm{~g}$ \\
\hline Wounding+(IBA+V $\left.\mathrm{V}_{\mathrm{B} 12}\right)$ & $T_{14}$ & $37.67 \mathrm{c}$ & $38.00 \mathrm{c}$ & $37.84 \mathrm{c}$ & $15.40 \mathrm{c}$ & $15.43 \mathrm{c}$ & $15.42 \mathrm{c}$ & $6.04 \mathrm{~d}-\mathrm{f}$ & $6.10 \mathrm{de}$ & $6.07 \mathrm{e}-\mathrm{g}$ & $8.07 \mathrm{c}$ & $8.15 \mathrm{~b}$ & $8.11 \mathrm{~b}$ \\
\hline
\end{tabular}


Samaan, L. G. et al. 